\title{
Genetic Diversity Pattern of Marine Bacterial Strains Using Random Amplified Polymorphic DNA (RAPD) Technique
}

\author{
Meshaal J. Sabir ${ }^{1}$; Nahid H. Hajrah ${ }^{1}$ and Salah E. M. Abo-Aba ${ }^{1,2}$. \\ 1Department of Biological Sciences, Faculty of Science, King Abdulaziz University, Jeddah, Saudi Arabia, \\ 2Microbial Genetics Department, Genetic Engineering and Biotechnology Division, National Research Centre, Giza, \\ Egypt.
}

\begin{abstract}
A random amplified polymorphic DNA (RAPD) fingerprinting method has been used to fingerprint isolated marine bacterial strains. Six RAPD primers were used to differentiate 10 selected bacterial strains. Amplifications performed with primers UBC73, UBC88, UBC92, UBC96, UBC55 and UBC67 generate the best RAPD profiles. Dendrogram assessed by RAPD-PCR using six used primers yielded good banding patterns and showed that there is genetic diversity among strains. The RAPD profiles revealed a high level of DNA sequence diversity. Hence, this study, demonstrated that the local marine bacterial strains in this studied area are populated by genetically polymorphic strains. In addition, RAPD-PCR is simple, robust and sensitive typing methods to differentiate the isolated bacterial strains.
\end{abstract}

Key words: Marine bacteria, RAPD-PCR, Dendogram, DNA.

\section{Introduction}

The RAPD method has been widely used in research to study population genetic structure ${ }^{[1]}$, mutagenesis ${ }^{[2]}$, genetic mapping ${ }^{[3]}$, and phylogenetics ${ }^{[4 ; 5]}$ for a variety of species.

The random amplified polymorphic DNA (RAPD) technique based on the polymerase chain reaction (PCR) has been identified as one of the most commonly used molecular techniques to develop DNA markers. RAPD markers are amplification products of anonymous DNA sequences using single, short and arbitrary oligonucleotide primers, and thus do not require prior knowledge of a DNA sequence. Low expense, efficiency in developing large number of DNA markers in a short time and requirement for less sophisticated equipment has made the RAPD technique valuable $^{[6 ; 7 ; 8 ; 9]}$.
Several recent studies supported the utilization of the RAPD technique to characterize individuals among bacterial species to conduct phylogenetic relationships and to detect genetic variability among closely related species to reveal genetic markers for certain trait ${ }^{[10]}$.

RAPD analysis is a commonly used method in PCR. This fingerprint has been used for typing and differentiation of bacteria and, increasingly, for the study of genetic relationships between strains and species of microorganisms, plants and animals ${ }^{[11]}$.

The marine habitate with complex and highly active attached microbial communities, and the free-living bacteria which are small in size but extremely abundant on a global scale due to the large volume of the oceans [12]

The aim of the present investigation was to use RAPD-PCR assay to 
generate polymorphism in DNA patterns amenable to the differentiation of the isolated marine strains isolated from Res Sea near Jeddah city. In this study we determined the DNA diversity of isolated marine bacterial strains by RAPD-PCR which allows rapid and sensitive differentiation between the selected strains.

\section{Materials and methods}

\section{Red sea Sample Collections:}

Red sea water samples were collected from different depth of Jeddah, Saudi Arabia. The collected samples are summarized in Table 1. Collected and stored in sterile plastic cups at $-20 \mathrm{oC}$.

\section{Isolation of marine bacteria:}

Collected samples suspended in $5 \mathrm{~mL}$ test tubes containing marine broth [13]. Suspensions were incubated overnight at $30{ }^{\circ} \mathrm{C}$ with shaking. Plated on marine agar and incubated at $30 \mathrm{oC}$ overnight. Bacterial like colonies speeded over marine agar plates and single colonies were picked up and streaked in the same plates.

\section{Molecular characterization}

\section{Genomic DNA extraction}

Genomic DNA was extracted from ten studied isolates using Easy Quick DNA extraction kit (Genomix) following the manufacturer's instructions.

\section{$16 \mathrm{r}$ RNA sequence analysis:}

\section{Random amplified polymorphic DNA (RAPD-PCR):}

PCR reactions were carried out using six arbitrary 10-mer primers (Bioneer Trade Shanghi Co, Ltd.). PCR reactions were conducted using GoTaq Green Mix. 2x Promiga with $10 \mathrm{P}$ mol of each 6 different arbitrary 10-mer primers. The codes and sequences of these primers are listed in Table 2 . The $25 \mu 1$ reaction mixture was (10 Pmol. of each primer, 30-50 ng of DNA template and $12.5 \mu \mathrm{l}$ of GoTaq Green Mix. 2x Promiga). The PCR protocol was initial denaturation, $94 \mathrm{oC}$ for $2.5 \mathrm{~min}$ and 35 cycles of subsequent denaturation, 94 ${ }^{\circ} \mathrm{C}$ for $45 \mathrm{~s}$; annealing temperature, 37 ${ }^{\circ} \mathrm{C}$ for $30 \mathrm{~s}$; extension temperature, $72{ }^{\circ} \mathrm{C}$ for $2 \mathrm{~min}$ and final extension, $72{ }^{\circ} \mathrm{C}$ for $10 \mathrm{~min}$. PCR products were analyzed on $10 \times 14 \mathrm{~cm} 1 \%$ agarose gel electrophoresis with DNA ladder standard 100 bp (RTU Gene Direct) for 30 min using Tris-borate- EDTA Buffer and visualized by ultraviolet illumination after staining with 0.5 $\mu \mathrm{g} / \mathrm{ml}$ ethidium bromide.

\section{RAPD data analysis}

The presence / absence RAPD data were analyzed using the SPSS-PC programs of ${ }^{[14]}$. Pairwise comparisons between strains were used to calculate the genetic similarity values (F) derived from Dice similarity coefficient.

\section{Oligonucleotide (RAPD) Primers used in this study:}

The RAPD primers have been used in this study are listed in Table 2. A pair of RAPD for each 6 primers was applied to amplify isolated DNA from isolated marine bacterial strains under study. Their sequences and total scored fragments produced by each primer among 10 studied isolates are shown in Table 2.

\section{Results}

10 marine bacterial strains recovered from Red Sea near Jeddah city Saudi 
Arabia were compared using random amplification of polymorphic DNA (RAPD-PCR) to fingerprint at the molecular level. Total genomic DNA from each isolated strains were amplified using 6-mer primers. Electrophoreses analysis of the amplification products revealed that incidence of polymorphism among the isolates. Pair-wise comparisons of polymorphic products were used to construct a dendrogram applying the cluster analysis. Results showed variation among the isolated strains.

10 isolated marine bacterial strains (Table 1) representing different genus and species according to 16 s sequencing analysis were characterized by six randomly amplified polymorphic DNA (RAPD) markers (Table 2) to determine their genetic diversity patterns.

Table (1) : Isolated marine bacterial strains after 16 s identification

\begin{tabular}{|l|l|}
\hline No & Identified strain \\
\hline 1 & Halomonas $s p$. \\
\hline 2 & Psoudoaltromonas sp. \\
\hline 3 & Viprio parhaemolyticus \\
\hline 4 & Marinibacter $s p$. \\
\hline 5 & Citreicella thiooxidans \\
\hline 6 & Psicobacter $s p$. \\
\hline 7 & Salegentibacter sp. \\
\hline 8 & Nitratrieductor aquipiodomus \\
\hline 9 & Psoudoaltromonas sp. \\
\hline 10 & Planococcus citreus \\
\hline
\end{tabular}

Table (2): list of used primers and their nucleotide sequences.

\begin{tabular}{|c|c|}
\hline Used primers & sequence \\
\hline UBC73 & GGGCACGCGA \\
\hline UBC88 & CGGGGGATGG \\
\hline UBC92 & CCTGGGCTTT \\
\hline UBC96 & GGCGGCATGG \\
\hline UBC55 & TCCCTCGTGC \\
\hline UBC67 & GAGGGCGAGC \\
\hline
\end{tabular}

A result based on electrophoreses analysis of the amplification products showed that each isolated strains represented different according to their banding patterns and dendogram construction. All primers showed amplification and banding profiles were obtained and revealed a high degree of variability among the isolated strains, and also concluded that our isolated strains are gnomically diverse.

Primer UBC73 amplified different polymorphic fragments with all subjected DNA from each bacterial strain, with different amplicon sizes as shown in Fig. (1).

Cluster analysis of primers UBC73 generated 23 different banding patterns with 15 unique bands, no monomrphic bans were produced. The polymorphism were $100 \%$ with such used primer

Primer UBC88 yielded 26 different patterns with 17 unique bands. No monomrphic bans were produced, polymorphism were $100 \%$. Primer UBC92 yielded 28 bands pattern with $100 \%$ polymorphism with 28 polymorphic bands with unique bands. While primer UBC96 generate 25 total numbers of bands and no monomrphic bands produced with polymorphism $100 \%$. The primer UBC55 yielded 22 banding patterns with $100 \%$ polymorphism and also no monomrphic bans were produced. The last used primer was UBC67 produce 32 total number of bands without any monomrphic bands and the polymorphism were also $100 \%$.

A dendogram was constructed to understand their phylogeny tree based on the combined similarity matrix 
generated with the two RAPD primers is presented in Figure 2.

Genetic similarity and distance values calculated from amplified DNA bands with each six used RAPD primer were represented in Figure 3.
The obtained banding pattern revealed high percentage of genetic variation among studied Strains and introduced great genetic differentiation of all used strains.

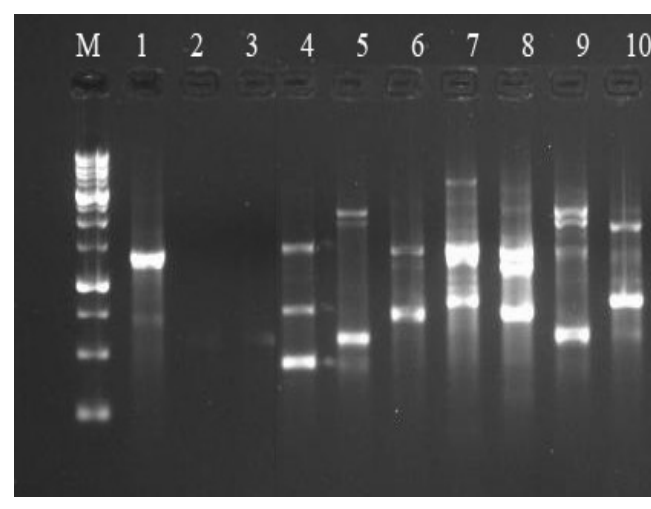

Primer UBC92

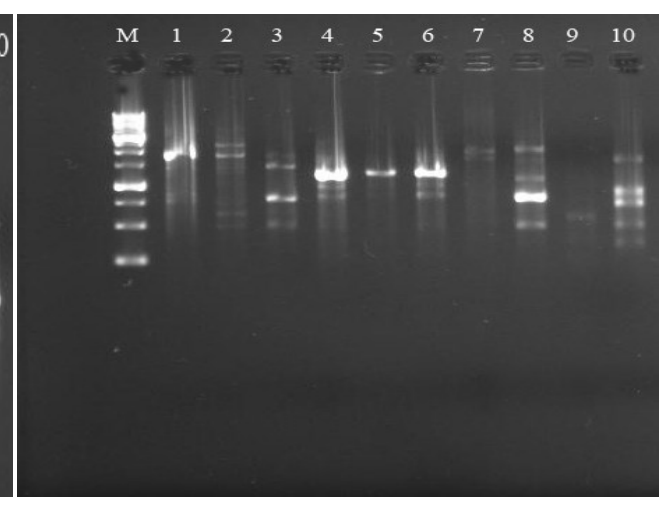

primer UBC96
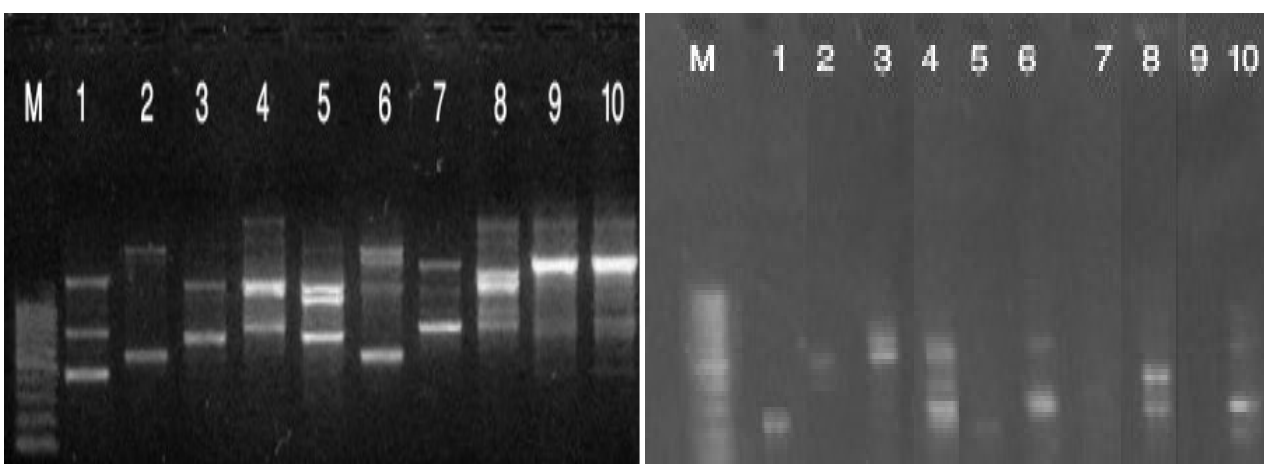

Primer 5

primer 6
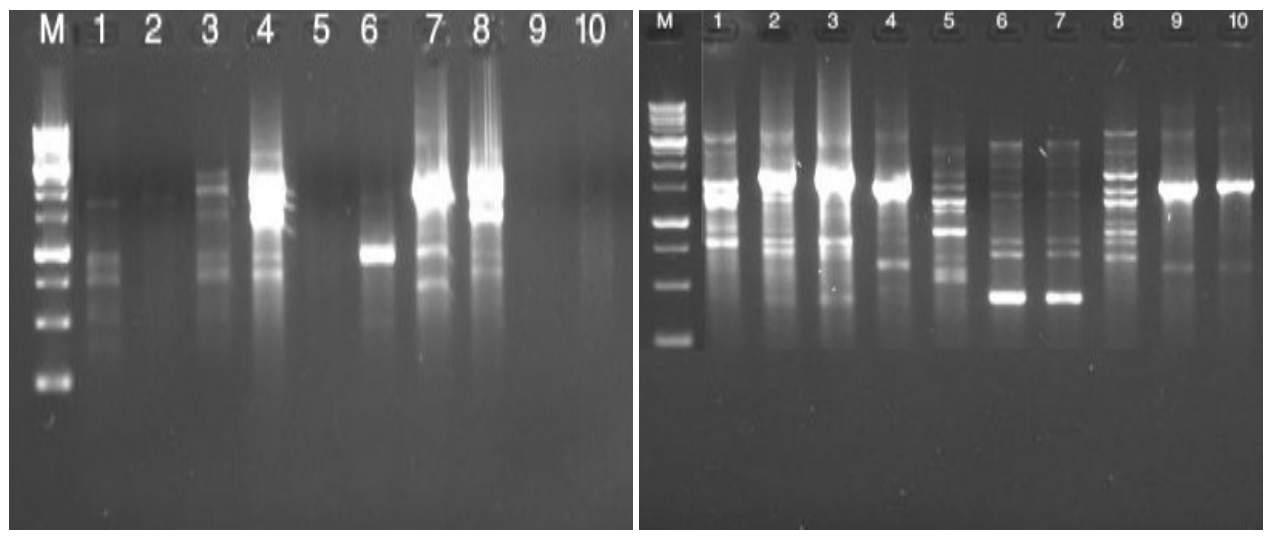

Fig. (1): RAPD-PCR banding pattern obtained from different 10 marine bacterial strains generated by each random primer 
Primer UBC73

Rescaled Distance cluster Combine

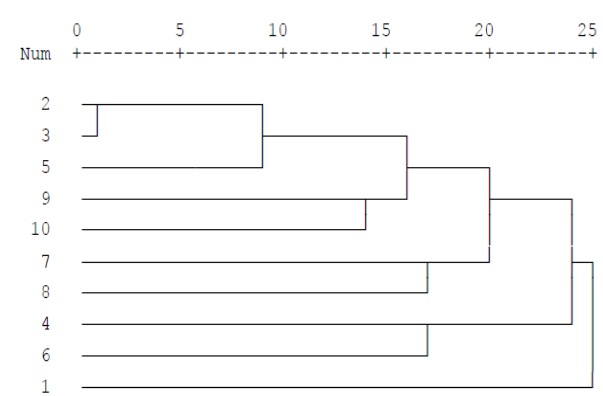

rimer UBC92

Rescaled Distance Cluster Combine

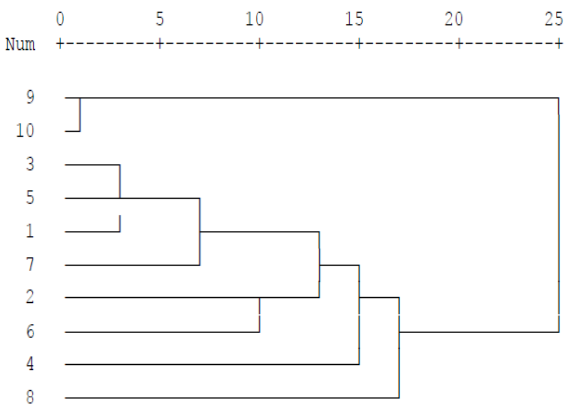

Primer 5

Rescaled Distance Cluster Combine

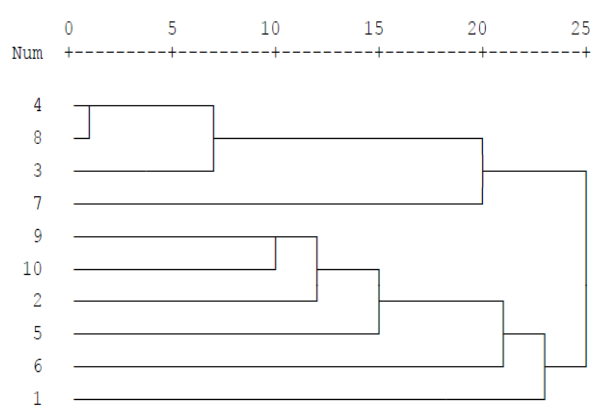

primer UBC88

Rescaled Distance Cluster Combine

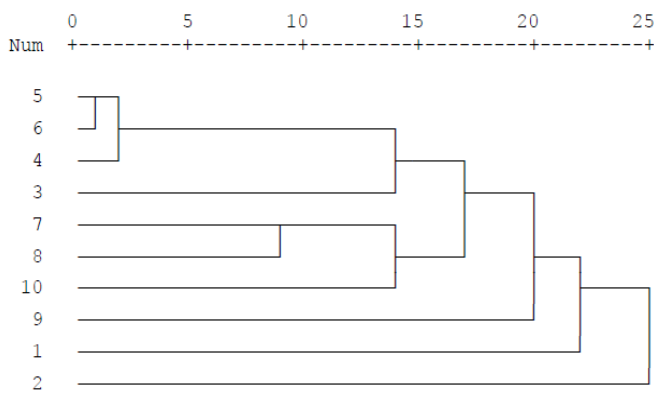

primer UBC96

Rescaled Distance Cluster Combine

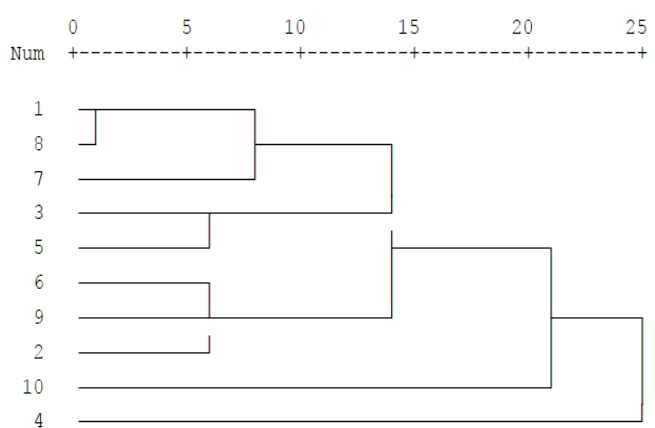

primer 6

Rescaled Distance Cluster Combine

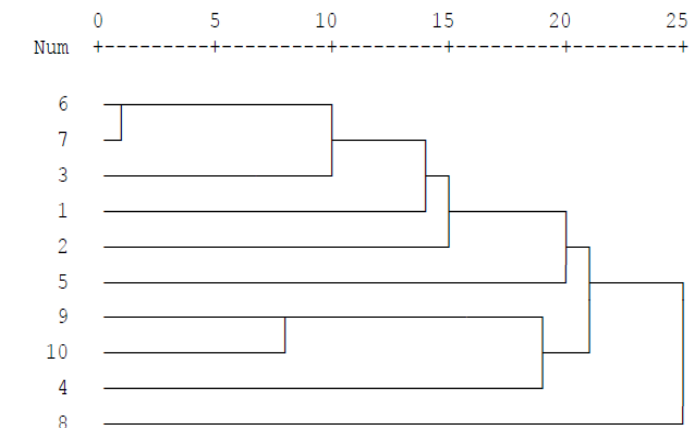

Fig. (2): Dendogram analysis using average linkage between 10 isolated strains with each used primers. 
Primer UBC73

\begin{tabular}{|l|l|l|l|l|l|l|l|l|l|l|}
\hline \multirow{2}{*}{ Strains } & \multicolumn{10}{|c|}{ Matrix file input } \\
\cline { 2 - 12 } & 1 & 2 & 3 & 4 & 5 & 6 & 7 & 8 & 9 & 10 \\
\hline 1 & & & & & & & & & & \\
\hline 2 & .636 & & & & & & & & & \\
\hline 3 & .545 & 1.000 & & & & & & & & \\
\hline 4 & .273 & .545 & .455 & & & & & & & \\
\hline 5 & .364 & .818 & .727 & .455 & & & & & & \\
\hline 6 & .455 & .545 & .455 & .545 & .373 & & & & & \\
\hline 7 & .273 & .545 & .636 & .364 & .455 & .364 & & & & \\
\hline 8 & .273 & .545 & .455 & .545 & .455 & .545 & .545 & & & \\
\hline 9 & .000 & .455 & .545 & .273 & .727 & .091 & .455 & .273 & & \\
\hline 10 & .091 & .545 & .636 & .182 & .636 & .182 & .545 & .364 & .636 & \\
\hline
\end{tabular}

Primer UBC92 primer UBC88

\begin{tabular}{|l|l|l|l|l|l|l|l|l|l|l|}
\hline & \multicolumn{10}{|c|}{} \\
\cline { 2 - 12 } & 1 & 2 & 3 & 4 & 5 & 6 & 7 & 8 & 9 & 10 \\
\hline 1 & & & & & & & & & & \\
\hline 2 & .273 & & & & & & & & & \\
\hline 3 & .545 & .545 & & & & & & & & \\
\hline 4 & .364 & .273 & .636 & & & & & & & \\
\hline 5 & .364 & .019 & .455 & .909 & & & & & & \\
\hline 6 & .273 & .182 & .545 & 1.000 & 1.000 & & & & & \\
\hline 7 & .273 & .000 & .364 & .237 & .455 & .364 & & & & \\
\hline 8 & .273 & .182 & .545 & .636 & .636 & .727 & .727 & & & \\
\hline 9 & .273 & .000 & .364 & .455 & .455 & .364 & .364 & .364 & & \\
\hline 10 & .182 & .091 & .455 & .364 & .364 & .455 & .455 & .636 & .273 & \\
\hline
\end{tabular}

primer UBC96

\begin{tabular}{|l|l|l|l|l|l|l|l|l|l|l|}
\hline & \multicolumn{10}{|c|}{} \\
\cline { 2 - 11 } & 1 & 2 & 3 & 4 & 5 & 6 & 7 & 8 & 9 & 10 \\
\hline 1 & & & & & & & & & & \\
\hline 2 & .571 & & & & & & & & & \\
\hline 3 & .929 & .571 & & & & & & & & \\
\hline 4 & .571 & .500 & .571 & & & & & & & \\
\hline 5 & .929 & .714 & .929 & .714 & & & & & & \\
\hline 6 & .634 & .714 & .643 & .571 & .786 & & & & & \\
\hline 7 & .786 & .429 & .786 & .429 & .786 & .643 & & & & \\
\hline 8 & .634 & .286 & .634 & .286 & .643 & .357 & .500 & & & \\
\hline 9 & .375 & .286 & .375 & .286 & .357 & .214 & .214 & .071 & & \\
\hline 10 & .268 & .241 & .286 & .214 & .286 & .143 & .143 & .000 & 1.000 & \\
\hline
\end{tabular}

Primer 5

\begin{tabular}{|l|l|l|l|l|l|l|l|l|l|l|}
\hline & \multicolumn{10}{|c|}{} \\
\cline { 2 - 12 } & 1 & 2 & 3 & 4 & 5 & 6 & 7 & 8 & 9 & 10 \\
\hline 1 & & & & & & & & & & \\
\hline 2 & .667 & & & & & & & & & \\
\hline 3 & .667 & .500 & & & & & & & & \\
\hline 4 & .333 & .167 & .167 & & & & & & & \\
\hline 5 & .667 & .833 & .833 & .167 & & & & & & \\
\hline 6 & .667 & .883 & .500 & .167 & .500 & & & & & \\
\hline 7 & .667 & .500 & .500 & .500 & .500 & .500 & & & & \\
\hline 8 & 1.000 & .500 & .500 & .167 & .500 & .500 & .833 & & & \\
\hline 9 & .667 & .833 & .500 & .167 & .500 & .833 & .500 & .500 & & \\
\hline 10 & .500 & .333 & .333 & .000 & .333 & .333 & .333 & .333 & .333 & \\
\hline
\end{tabular}

primer 6

\begin{tabular}{|l|l|l|l|l|l|l|l|l|l|l|}
\hline & \multicolumn{10}{|c|}{} \\
\cline { 2 - 13 } & 1 & 2 & 3 & 4 & 5 & 6 & 7 & 8 & 9 & 10 \\
\hline 1 & & & & & & & & & & \\
\hline 2 & .222 & & & & & & & & & \\
\hline 3 & .222 & .111 & & & & & & & & \\
\hline 4 & .222 & .111 & .778 & & & & & & & \\
\hline 5 & .111 & .444 & .222 & .000 & & & & & & \\
\hline 6 & .111 & .222 & .222 & .000 & .333 & & & & & \\
\hline 7 & .000 & .111 & .333 & .333 & .000 & .222 & & & & \\
\hline 8 & .222 & .111 & .778 & 1.000 & .000 & .000 & .333 & & & \\
\hline 9 & .333 & .668 & .222 & .222 & .556 & .333 & .222 & .222 & & \\
\hline 10 & .222 & .556 & .111 & .111 & .444 & .222 & .111 & .111 & .667 & \\
\hline
\end{tabular}

\begin{tabular}{|l|l|l|l|l|l|l|l|l|l|l|}
\hline \multirow{2}{*}{} & \multicolumn{10}{|c|}{} \\
\cline { 2 - 12 } & 1 & 2 & 3 & 4 & 5 & 6 & 7 & 8 & 9 & 10 \\
\hline 1 & & & & & & & & & & \\
\hline 2 & .375 & & & & & & & & & \\
\hline 3 & .563 & .365 & & & & & & & & \\
\hline 4 & .375 & .250 & .438 & & & & & & & \\
\hline 5 & .250 & .250 & .438 & .250 & & & & & & \\
\hline 6 & .500 & .500 & .688 & .375 & .375 & & & & & \\
\hline 7 & .500 & .500 & .688 & .375 & .375 & 1.000 & & & & \\
\hline 8 & .000 & .125 & .188 & .125 & .000 & .250 & .250 & & & \\
\hline 9 & .313 & .188 & .375 & .313 & .188 & .188 & .188 & .188 & & \\
\hline 10 & .438 & .188 & .500 & .438 & .188 & .188 & .188 & .063 & .750 & \\
\hline
\end{tabular}

Fig. (3): Genetic similarity and distance values calculated from amplified DNA bands with each six used RAPD primers 


\section{Discussion}

Molecular characterization techniques are widely used both for differentiation of bacteria ${ }^{[15 ; 12]}$ and cyanobacteria $^{[16]}$.

In the present study molecular genetics characterization of 10 marine bacterial strains were using six RAPDPCR to fingerprinting and phylogenetic relatedness among them.the results of RAPD analysis are reproducible and generated several bands, the banding patterns observed were almost different and clearly revealed the range of genetic diversity, these results are in agreement with several literatures ${ }^{[15 ; 17 ; 18]}$.

The banding patterns generated by six used primers showed variation between strains this is clearly indication about genetic variability of isolated strains and also no similarity were shown in RAPD data analysis. This indicates that high percentage of genetic variation among studied Strains as shown by ${ }^{[19 ; 20]}$.

Cluster analysis based on combined similarity matrix grouped all strains into different clusters, indicating a genetically variability of isolated strains. Our observations are in agreement with previous studies [19]. The ability of RAPD-PCR to variability of marine bacterial strains under study suggests that this technique could be used in differentiating these strains. No correlation was obtained between a given RAPD type and the geographical location or the source of the isolates. Further studies are important to clarify in establishing the important of these isolated strains.

In this study, RAPD-PCR were reproducible and generated several bands, the banding patterns observed were almost different and shown high percentage of genetic variation among studied strains and concluded that RAPD-PCR which is a rapid and simple tool could be used in typing and differentiating a large number of isolated marine bacterial strains and concluded that the isolated strains were genetically diverse.

\section{References}

[1] Lynch, M. and Milligan, B. G. Analysis of population genetic structure with RAPD markers, Mol. Ecol. 3, 91-99. (1994).

[2] Papadopoulos, S., Benter, T., Anastassiou, G., Pape, M., Gerhard, S., Bornfeld, N., Ludwig,W. D. and B. Dorken . Assessment of genomic instability in breast cancer and uveal melanoma by random amplified polymorphic DNA analysis, Int. J. Cancer 99, 193-200. (2002).

[3] Endre, G., Kalo, P., Kevei, Z., Kiss, P., Mihacea, S., Szakal, B., Kereszt, A. and Kiss, G. B. Genetic mapping of the non-nodulation phenotype of the mutant MN-1008 in tetraploid alfalfa (Medicago sativa), Mol. Genet. Genomics 266, 1012-1019. (2002).

[4] Dillman, C. D., Banks, S. M., Vorderstrasse, T. J. and Eckdahl, T. T. Phylogenetic analysis of Missouri populations of longear sunfish, Lepomis megalotis, Bios 71, 2-8. (2000).

[5] Gasper, B. R., Koppelman, J. B., Schwery, S. P. and Eckdahl T. T. Molecular phylogenetic analysis of Missouri sculpins, Am. Midl. Nat. 146, 264-270. (2001).

[6] Callejas C., and Ochando, M.D. Identification of Spanish barbel species using the RAPD technique. Journal of Fish Biology, v. 53, p. 208215. (1998).

[7] Elvervoll, E.O., Sorensen, N.K.,Osterud, B., Ofstad, R., Martinez, I. Processing of marine foods. Meat Science, v. 43, p. S265-S275. (1996).

[8] Welish, J., Mcclelland, M. Fingerprinting genomes using arbitrary primers. Nucleic Acids Research, v. 18, p. 7213-7218, (1990).

[9] Williams, J.G.K.; Kubelik, A.R.; Livak, K.J.; Raflaski, J.A.; Tingey, S.V. DNA 
polymorphisms amplified by arbitrary primers are useful genetic

markers. Nucleic Acid Research, v. 18, p. 6531-6535, (1990)

[10] Arif, I.A. . Bakir, M.A., Khan, H.A.,Al Farhan, A.H., Al Homaidan,A.A., Bahkali,A.H. Al Sadoon, M. and Shobrak, M. Application of RAPD for molecular characterization of plant species of medicinal value from an arid environment. Genetics and Molecular Research, 9 (4): 2191-9198. (2010).

[11] Oakey, H. J., Gibson, L.F. and A.M. George, Co-migration of RAPD-PCR amplicons from Aeromonas hydrophila. FEMS Microbiol. Lett. 164: 35-38. (1998).

[12] DeLong, E.F., Franks, D.G. and Alldredge, A.L. Phylogenetic diversity of aggregateattached vs. free-living marine bacterial assemblages. Limnol. Oceanogr. 38, 924-934. (1993).

[13] Joint,I., Mühling M., and Querellou, J. Culturing marine bacteria - an essential prerequisite for biodiscovery. Microbial Biotechnology 3(5), 564-575. (2010).

[14] Norusis, M. J. SPSS/PC1 for the IBM PC/XT/AT. SPSS Inc., Chicago, Ill. (1986).

[15] Maiti B, Shekar M, Khushiramani, R. and Karunasagar . R. Evaluation of RAPD-PCR and protein profile analysis to differentiate Vibrio harveyi strains prevalent along the southwest coast of India. J. Genet. 88 (3): 2739. (2009).
[16] Praveen-Kumar, R., Vijayan, D., Leo Antony, M., Muthu Kumar, C. and Thajuddin, N. Phylogenetic diversity of cultivable bacteria associated with filamentous non-hetrocystous marine cyanobacteria. J. Algal Biomass Utln. 1 (1): 86 - 101. (2009).

[17] Beeson, K.E., Erdner, D. L., Bagwell, C. E., Lovell, C. R. and Sobecky P. A. differentiation of plasmids in marine diazotroph assemblages determined by randomly amplified polymorphic DNA analysis. Microbiology 148, 179-189. ( 2002).

[18] Nawas, P.M.A., Ramasubberayan, R., Palavesam, A. and Immanuel, G. RAPD analysis of dominant dintrifying bacterial species in the estuarine environment of south west coast of india. Indian Journal of Geo Marine science. 1696- 1703. (2016).

[19] Avendaño-Herrera, R.., Rodríguez, J., Magariños, B., Romalde, J.L. and Toranzo, A.E. Intraspecific diversity of the marine fish pathogen Tenacibaculum maritimum as determined by randomly amplified polymorphic DNA-PCR. J Appl Microbiol. 96(4):871-877. (2004).

[20] Labella A, Manchado M, Alonso MC, Castro D, Romalde JL, Borrego JJ. Molecular intraspecific characterization of Photobacterium damselae ssp. damselae strains affecting cultured marine fish. J Appl Microbiol. 108 (6):2122-32. (2010). 


\title{
التنوع الوراثي لسلالات بكتيرية بحرية باستخذام تقتية واسمات الحمض النووي متعدد الأثكال العشوائي المضخم (رابد)
}

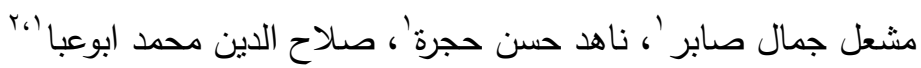

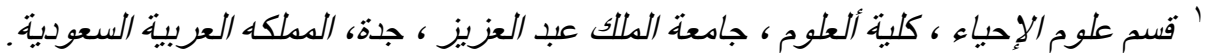

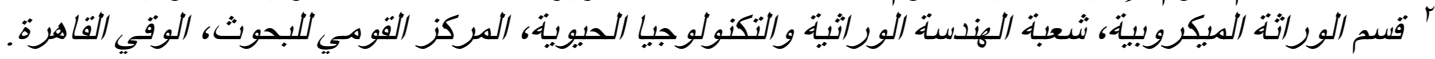

المستخلص: تم استخدام طريقة تضخيم الحمض النووي متعدد الأشكال العشوائى باستخدام واسمات

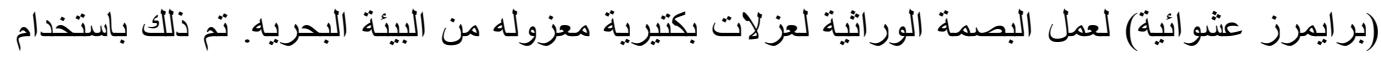

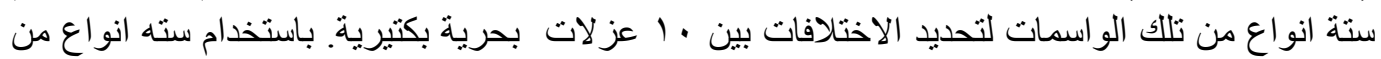

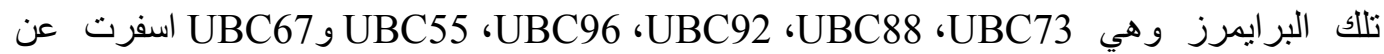

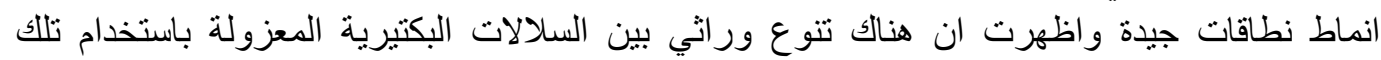

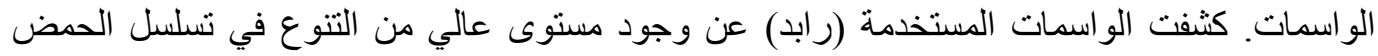

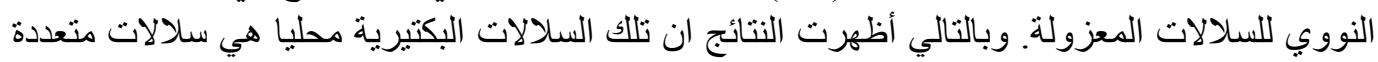
الانثال ور اثيا. و أن الو اسمات المستخدمة قوية وحساسة للتمييز بين تلك السلالات البكتية الكتيرية.

كلمات مفتاحية : البكتريا البحرية ، DNA DDendogram ، RAPD-PCR. 